Пилипчук Н. П., аспірантка Інституту держави і права імені В. М. Корецького НАН Украӥни ORCID: 0000-0002-5553-8524

\title{
ПРОБЛЕМИ ЗАБЕЗПЕЧЕННЯ КОНСТИТУЦЙНОГО ПРАВА ЛЮДИНИ Й ГРОМАДЯНИНА НА ВІДПОЧИНОК В УКРАЇНІ
}

У статті здійснено аналіз проблем забезпечення конституційного права людини й громадянина на відпочинок в Україні. 3'ясовано зміст кожної із наведених проблем. Обгрунтовано як законодавчі прогалини впливають на практику. Сформульовано чіткі та аргументовані пропозиції щодо вирішення наведених проблем.

Ключові слова: проблеми забезпечення права; конституційне право; людина й громадянин; право на відпочинок; конституція.

В статье проведен анализ проблем обеспечения конституционного права человека и гражданина на отдых в Украину. Выяснено содержание каждой из указанных проблем. Обоснованно как законодательные пробелы влияют на практику. Сформулированы четкие и аргументированно предложения по решению указанных проблем.

Ключевые слова: проблемы обеспечения права; конституционное право; человек и гражданин; право на отдых; конституция.

Постановка проблеми. На сьогодні, гостро стоїть проблема комплексного вирішення негативних аспектів конституційного регулювання, що дозволили б ефективно здійснювати вплив на суспільні відносини, а не частково долати певні законодавчі прогалини, створюючи при цьому нові колізії. Щодо конституційного права людини й громадянина на відпочинок в Україні, то його дослідження щодо проблем у кожному із механізмів реалізації, забезпечення та захисту надасть можливість визначити, як загальні напрями вдосконалення, так й залежно від рівня правового регулювання та ключових завдань.
Щодо забезпечення конституційного права людини й громадянина на відпочинок в Україні, то результати їх дослідження повинні бути націлені на з'ясування питання чи достатньою $\epsilon$ кількість конституційних гарантій реалізації даного права. Забезпечення права на відпочинок безпосередньо пов'язано із державною та громадською діяльністю щодо контролю дотримання обов'язків роботодавця та відповідності умов конституційним принципам та нормам. Таким чином, надані у результаті даного дослід-ження пропозиції дозволять покращити взаємодію між особами, що працюють та суб'єктами контролю їх відносин, що, 
зі свого боку, сприятиме утвердженню авторитету та довіри до держави, а отже й забезпечуватиме стабільність досягнення ії завдань передбачених Конституцією.

Аналіз останніх досліджень i публікацій. Питання проблем забезпечення конституційного права людини й громадянина на відпочинок в Україні та пропозиції щодо їх вирішення досліджується постійно, однак внаслідок змінюваності суспільних потреб та новітніх тенденцій у правовому регулюванні значна частина робіт втрачає свою актуальність. Так, дослідженням окремих проблем реалізації, забезпечення та захисту конституційного права на відпочинок займались наступні науковці: М. В. Афанасьєва, Р. В. Бараннік, І. В. Бойко, О. І. Бойко, А. Ю. Денисевич, Т. С. Єрмолова, О.А. Жаров, О. А. Кравченко, Ю. Я. Коцан-Олинець, Ю. Р. Михалко, Н. П. Мокрицька, П. М. Петровський, А. А. Пилипенко, В. М. Попова, М. В. Савчин, В. В. Собченко, В. В. Хромей, А. С. Ярошенко.

Виклад основного матеріалу. Слід вказати, що однією із функцій Конституції України є саме гарантування реалізації прав шляхом визначення або ж заборон або покладенням обов'язків на певні державні органи. Разом з тим, ефективність такого гарантування $\epsilon$ доволі спірною. До прикладу, В. М. Попова визначає, що на жаль, конституційні норми відображають переважно, опосередкований тип діяльності держави в соціальній сфері. Не сформульована чітка і пряма відповідальність держави перед людиною i громадянином, а також індивіда перед державою» [1, с. 74]. У межах забезпечення права на відпочинок держава не має прямих обов'язків щодо матеріального забезпечення права на відпочинок або ж щодо контролю за його реалізацією. Важливою $є$ й відповідальність самої особи щодо зловживання правом на відпочинок, а також щодо справедливого розподілу тривалості й періоду такого відпочинку серед усіх членів трудового колективу. Також, право на відпочинок не відноситься до переліку прав, які не можуть бути обмежені відповідно до ст. 64 Конституції України [2]. Таке рі-шення є спірним враховуючи, що саме від можливості відпочити залежить рівень здоров'я особи. Звісно, за умов воєнного та надзвичайного стану реалізація права на відпочинок може бути обмежена, проте саме на рівні Конституції України необхідно вказати межі такого обмеження або ж визначити обов'язок законодавчого врегулювання питання. Під час вирішення питання максимального обсягу навантаження необхідно враховувати не лише досягнення результату, але й шкоду для здоров'я та саме рівноцінний її розподіл серед усіх працівників. Варто наголосити, про обов'язок роботодавця та державних органів щодо забезпечення й контролю за дотриманням рівного навантаження та відповідальність, як дисциплінарну, так й матеріальну за його недотримання.

На проблему забезпечення права на відпочинок вказує й А.С.Ярошенко, який зазначає, що Конституція гарантує працівникам лише право на щорічну оплачувану відпустку як елемент конституційного права на відпочинок. Інші види відпусток не є предметом прямих конституційних гарантій, оскільки не закріплюються в Конституції, але регулюються трудовим 
законодавством, з урахуванням норм міжнародного права, а також конституційними положеннями про право на освіту, виховання і догляд за дитиною та інше [3, с. 241]. Таким чином, можливо дійти висновку, про взаємозв'язок між правом на відпочинок та іншими конституційними правами. Проте, важливим $€$ саме їх розмежування, адже догляд за дитиною хоча й потребує звільнення від виконання трудових обов'язків не може вважатись саме відпочинком. Щодо забезпечення відпусток, перерв та вихідних, то насамперед воно може бути здійснено через встановлення обмежень робочого часу та визначення тривалості відпочинку. В межах конституційного регулювання не обхідним $\epsilon$ лише встановлення напряму та принципів, а не лише переліку форм реалізації. Ще однією проблемою $є$ недостатня деталізація правового регулювання обмеження нічного часу роботи, щодо переходу на літній/зимовий час, адже фактичний час роботи змінюється. Деталізації потребує й регулювання святкових та вихідних днів.

Найбільш точно дану проблему описує В. В. Хромей, що вказує на те, що «щодо віруючих римокатолицького, протестантського, юдейського, мусульманського чи іншого сповідування в КЗпП існує певна дискримінація. Зокрема ч. 2 ст. 73 КЗпП передбачено: за поданням релігійних громад інших (неправославних) конфесій, зареєстрованих в Україні керівництво підприємств, установ, організацій надає особам, які сповідують відповідні релігії, до трьох днів відпочинку протягом року для святкування їх великих свят 3 відпрацюванням цих днів [4, с. 147]. Слід вказати, що кількість осіб віро- сповіданням яких $\epsilon$ не православ'я може бути замалою для створення саме релігійної громади, що не повинно бути підставою для обмеження права на святкування релігійного свята. Тобто, насамперед, дискримінація відбувається через численну перевагу осіб однієї релігії. Така ситуація не лише порушує загальні конституційні права та заборону на дискримінацію, але й не може вважатись засобом саме забезпечення через реальну ускладненість такої процедури. Крім того, спірним є положення щодо відпрацювання наданих днів, адже такі свята, як Різдво або ж Великдень не відпрацьовуються, а у випадку потрапляння на вихідний день ще й переносяться на робочий. Фактично ж, відбувається захист й забезпечення не права працівника на відпочинок, а права роботодавця на отримання прибутку. Слід також й доповнити, що отримання звернення від релігійної громади, ще не визначає обов'язку роботодавця затвердити такі вихідні, адже це створює додаткові навантаження.

Щодо вирішення такої ситуації, то на рівні Конституції України необхідним є деталізації права на відпочинок, як одного із прикладів виразу свободи віросповідання, що $\mathrm{y}$ свою чергу дозволить краще тлумачити способи його забезпе-чення 3 боку Конституційного Суду України. Крім того, варто вдосконалити механізм визначення таких святкових днів, які або включали б усі найбільш великі свята усіх релігій або ж виключали саме релігійні свята із переліку днів у які працівники офіційно звільненні від виконання трудових обов'язків. Можливим вирішенням ситуації $€$ також й покращення

(C) Пилипчук Н. П., 2019 
ситуації саме із діяльністю професійних спілок, що дозволить вирішувати питання вихідних днів навіть для одного працівника саме на рівні підприємства із відповідним обов'язком роботодавця щодо його затвердження.

Продовжуючи тему дискримінаційних положень щодо слід звернути увагу й на дослідження Г. С. Лопушняк, де визначено, що «конкретизуючи конституційні інструменти забезпечення соціальноекономічних прав громадян, можна зробити висновок, що існуюча система пільг і соціальних гарантій, передусім, орієнтована на підвищення соціального захисту окремих соціальних груп, які здебільшого формуються за професійною ознакою (наприклад, військовослужбовці, працівники правоохоронних органів, судді та інші), а не на надання мінімально необхідного соціального забезпечення найбільш соціально незахищеним верствам населення (наприклад, інвалідам, пенсіонерам, тяжко хворим тощо)» [5, с. 69]. Дане твердження стосується й забезпечення права на відпочинок, оскільки саме для осіб, що перебувають у відносинах із роботодавцем-державою передбачені такі соціальні гарантії, як безкоштовні оздоровчі курорти або ж продовження часу відпустки. Разом 3 тим, зрозумілою $є$ потреба більшої тривалості відпочинку для осіб із інвалідністю або ж неповнолітніх осіб. Забезпечення права на відпочинок останніх відбувається шляхом обмеження робочого часу, однак не враховується поєднання його із часом на відвідування навчальних закладів та виконання обов'язків учня або студента, що значно зменшує час на відпочинок.
I. В. Бойко, аналізуючи правове регулювання часу на відпочинок вказує, що «у правників-юристів натепер немає чіткого розуміння того, чим саме є для працівника використання трудової відпустки - правом чи обов'язком, тому виникають питання щодо врегулювання правозастосовного характеру, наприклад, через відсутність чіткої процедури визначення строків трудових відпусток, тому деякі працюючі частково користуються правом на неї. Нині ще чітко не визначено диференційного правового регулювання в наданні працівникам трудових відпусток роботодавцями [6, с. 127]. Таким чином, серед помилок правового регулювання можливо й визначити невідповідність між способами правового регулювання. Оскільки право на відпочинок $є$ саме правом, то його реалізація $\epsilon$ виключним бажанням працівника, а отже й норми щодо тривалості робочого дня чи вихідних можуть бути порушені саме за бажанням останнього. Тобто, створюється ситуація, коли забезпечення права на відпочинок з боку держави фактично обмежує його.

Також, спірним $\epsilon$ саме порядок реалізації обов'язку щодо надання відпусток саме роботодавцем. В контексті забезпечення даного права державою необхідним $\epsilon$ встановлення гарантій отримання права на відпустку у визначенні строки або ж отримання обгрунтованої відповіді роботодавця щодо перенесення таких строків. Крім того, існує й потреба у встановленні критеріїв розподілу відпусток, оскільки така прогалина створює умови до зловживання 3 боку роботодавця, розподілу відпусток протягом року із врахуванням особистих вподобань або ж неприяз- 
ні. Крім того, відсутні й строки затвердження відпустки.

Таким чином, можливо дійти висновку, що хоча конституційне право на відпочинок працівника та кореспондуючий йому обов'язок роботодавця визначено на рівні законодавства, проте гарантій його втілення $\epsilon$ недостатньо. Така ситуація пов'язана із наявністю значних прогалин й колізій у законодавстві, що й формують наступні проблеми у забезпеченні конституційного права людини й громадянина на відпочинок:

1. Наявність дискримінації за віросповіданням.

2. Відсутність принципів обмеження права на відпочинок.

3. Прогалини у повноваженнях профспілок.

Найперше, проблеми із забезпечення права на відпочинок пов'язані зі відсутністю гарантій забезпечення рівної його реалізації. Конституцією встановлено заборону на дискримінацію за будь-якої із ознак, а також й свободу віросповідання, проте проблема полягає саме у створенні спільного механізму забезпечення й щодо права на відпочинок. Варто звернути увагу на ст. 73 КЗпПУ, відповідно якої до переліку святкових днів включено православні свята та католицьке Різдво, а ч. 2 даної статті передбачено, що «за поданням релігійних громад інших (неправославних) конфесій, зареєстрованих в Україні, керівництво підприємств, установ, організацій надає особам, які сповідують відповідні релігії, до трьох днів відпочинку протягом року для святкування їх великих свят з відпрацюванням за ці дні» [7]. Зазвичай, законодавчі норми, які суперечать конституційним принци-пам визнаються такими Конституційним судом України, однак звер-нення до нього є ускладненим та потребує ініціативи з боку органів влади. Оскільки не православні становлять релігійні громади меншість в Україні, то відповідно й захист їх прав, в тому числі щодо права на відпочинок $є$ менш активним. Таким чином, існує ситуація порушення конституційних норм, що фактично, унеможливлюють реалізацію права на відпочинок для тих осіб, що працюють, які належать до інших релігійних громад. Вирішення такої ситуації є можливим виключно через зміну законодавства та залучення щодо нагляду та сприяння конституційних органів. Оскільки, КСУ не може створювати власні норми права, то більш доречним $\epsilon$ надання повноважень щодо нагляду й контролю КМУ, які через видання нормативних актів зможуть більш оперативно забезпечувати дотримання конституційного принципу рівності.

У даному контексті, слід наголосити на неможливості точного контролю за віросповіданням особи та ведення відповідних реєстрів як в межах підприємства, так й в межах держави. Тобто, вдосконалення норми права повинно відбуватись через застосування засобів відповідальності та гарантування позитивної відповіді. Щодо останнього, то вона може бути гарантована, як через застосування засобів компенсації витрат щодо відпочинку таких осіб, так й через визначення чіткого автоматизованого процесу встанов-лення святкових днів.

Наступною проблемою забезпечення права на відпочинок $\epsilon$ відсутність принципів обмеження права на відпочинок. Така норма сто- 
сується саме Конституції України, де закладаються основні інструменти гарантування права на відпочинок. Відповідно, їх аналіз вказує, що основним засобом гарантування $\epsilon$ власне нормування, однак на яких саме показниках повинні грунтуватись норми та від чого вони залежать не визначено. Проте, саме від основи формування нормативів робочого часу, тривалості відпочинку залежить й максимальні обмеження права на відпочинок, адже такі обмеження мають бути рівними для кожного хто, працює та мінімізувати шкідливі наслідки для організму, оскільки на обмеження права на життя та здоров'я людини уже існує конституційна заборона.

Щодо втілення конституційних норм в профільних законах, то відпочинок може бути обмежений у випадках встановлених ст. 71 КЗпПУ, до яких відноситься роботи невідкладні, наперед не передбачених робіт, від негайного виконання яких залежить у дальшому нормальна робота підприємства; метою запобігання або усунення простою рухомого складу чи скупчення вантажів у пунктах відправлення і призначення; ставлять або можуть поставити під загрозу життя чи нормальні життєві умови людей, загибелі або псування майна; для відвернення або ліквідації наслідків стихійного лиха, епідемій, епізоотій, виробничих аварій i негайного усунення їх наслідків [7]. Тобто, законодавчо визначенні основні критерії необхідності продовження роботи та скорочення тривалості права на відпочинок. Проте, описані ситуації необхідно розділити на ті, що не можуть бути передбачені та стосуються інтересів усього суспільства, як то стихійні лиха чи зупи- нятимуть рух транспорту, а отже відповідають критерію суспільної необхідності. Разом з тим, нормальна робота підприємства повинна бути спланована саме роботодавцем та саме на ньому лежить відповідальність за відшкодування.

Вирішенням даної ситуації потребує встановлення право мірності обмеження та ключового його критерію, який і визначатиме правомірність прийнятного рішення. Право на відпочинок $\epsilon$ нерозривним із конституційними правами на життя та здоров'я, а отже за відсутності можливості для його втілення обов'язковою $\epsilon$ компенсація, яка має покривати витрати на відновлення здоров'я та подолання психологічного стресу. Таким чином, ст. 45 Конституції України варто доповнити частиною 4, що буде мати наступ-ний зміст: «Обмеження права на відпочинок дозволено лише у випадках передбачених законом рівно-мірно щодо усіх працівників». Визначення принципу рівномірності дозволить зменшити шкоду здоров'ю особи, що працює та надалі розуміти чи були порушенні права на відпочинок щодо неї.

Також, ст. 107 КЗпПУ, де встановлено порядок оплати роботи у вихідні дні та святкові дні, роботу понаднормово, необхідно доповнити ч. 4 відповідно до якої «оплата праці працівника у випадках зазначених п. 1-3 ч. 2 ст. 71 даного Закону здійснюється за рахунок бюджету місцевої громади. Оплата праці працівника у випадку зазначеному п. 4 ч. 2 ст. 71 даного Закону здійснюється керівником організації, підприємства, установи». Таким чином, буде гарантовано право працівника на компенсацію витрат на лікування та 
відновлення здоров'я унаслідок правомірного обмеження та не реалізації права на відпочинок.

До проблем із забезпеченням права на відпочинок слід й віднести прогалини у повноваження профспілок. Відповідно до ст. 36 Конституції України «громадяни мають право на участь у професійних спілках 3 метою захисту своїх трудових і соціально-економічних прав та інтересів» [2]. Так, їх головним завдання $\epsilon$ саме представлення інтересів працівників у відносинах із роботодавцем, а також й їх захист. Однак, для виявлення інтересів та встановлення підстав для застосування засобів захисту необхідним $є$ здійснення моніторингу та контролю за реалізацію права на відпочинок та сприяння їй з боку роботодавця. Щодо моніторингу, то він й спрямований на визначення найбільш ефективних та гнучких способів реалізації, забезпечення та захисту права на відпочинок, не створюючи при цьому перешкод трудовому процесу та отримання прибутку підприємством. Проте, у ст. 21 Закону України «Про професійні спілки, їх права та гарантії діяльності» визначено, що «профспілки здійснюють громадський контроль за виплатою заробітної плати, додержанням законодавства про працю та про охорону праці, створенням безпечних і нешкідливих умов праці, належних виробничих та санітарнопобутових умов, забезпеченням працівників спецодягом, спецвзуттям, іншими засобами індивідуального та колективного захисту» [8]. Відповідно, повноваження щодо контролю за втіленням права на відпочинок, що в повному обсязі не входить до жодної із перелічених сфер не передбачено. Крім того, аналіз даного законодав- чого акту свідчить й про відсутність повноважень щодо моніторингу стану дотримання та втілення такого права. Така ситуація негативно впливає на рівень звернень до профспілок та значно зменшує потребу та продуктивність їх діяльності. Тобто, конституційне призначення профспілок не реалізується.

Вирішення даної проблеми полягає у визначенні конкретних завдань та призначення профспілок для кожного трудового права. Так, щодо права на відпочинок, то слід ст. 21 Закону України «Про професійні спілки, їх права та гарантії діяльності» змінити наступним чином: «профспілки здійснюють громадський контроль виплатою заробітної плати, додержанням законодавства про працю та про охорону праці та безперешкодною реалізацією права на відпочинок працівниками». Крім того, ст. 21 Закону України «Про Професійні спілки» слід й доповнити ч. 11 згідно з якою «Профспілки мають право на проведення постійного моніторингу стану дотримання Конституції України та трудового законодавства працівниками та роботодавцями на конкретному підприємстві». Моніторинг профспілок дозволить попереджати порушення права на відпочинок щодо працівників. Також, моніторинг дозволить гарантувати здійснення права на відпочинок не як окремого його виду щодо перерви чи відпустки, а комплексно, відслідковуючи в тому числі й вплив на психічне та фізичне здоров'я працівника.

Уже враховуючи такі зміни до законодавства, прогалини у повноваження профспілок варто й закріпити в спеціалізованому Законі України «Про відпустки», де слід допов-

(C) Пилипчук Н. П., 2019 
нити назву глави 7, яка буде звучати, як «громадський та державний нагляд, контроль і моніторинг за додержанням законодавства про відпустки та відповідальність за його порушення». Крім того, до даної глави варто й включити ст. 27-1, зміст якої буде наступним «Професійні спілки в межах своїх повноважень здійснюють нагляд та постійний моніторинг додержання законодавства про відпустки без втручання у діяльність підприємства, установи, організації. Професійні спілки зобов'язані повідомляти про порушення законодавства про відпустки компетентні органи визначні ст. 27 даного Закону». Таким чином, відбуватиметься взаємодія між інститутами суспільства та держави, а гарантування права на відпочинок відбуватиметься зацікавленими суб'єктами. Держава при цьому, як реалізуватиме конституційний обов'язок щодо ведення соціальної політики, так й здійснюватиме іï сучасними методами через режим максимального сприяння.

Висновки. Отже, на основі проведеного дослідження можливо дійти висновку, що для ефективного втілення права на відпочинок норми права необхідно вдосконалювати не відокремлено щодо лише захисту чи забезпечення, а створювати повноцінну норму права, що буде спрощувати, як їі вірне розуміння, так й застосування.

\section{Список використаних джерел}

1. Попова В. М. Соціальні права людини - основа соціальної держави. Ефективність державного управління, 2013. Вип. 37. С. 70-75.

2. Конституція України: Закон України від 28.06.1996 р. № 254к/96-ВР. Відомості Верховної Ради України (ВВР). 1996 р. № 30. Ст. 141.

3. Ярошенко А. С. Особливості правового регулювання відпусток, як гарантії держави, що надається працівнику. Актуальні проблеми трудового законодавства, законодавства про державну службу та службу в правоохоронних органах, 2018. № 1. C. 239-242.

4. Хромей В. В. Реалізація конституційного права на відпочинок. Зовнішня торгівля: економіка, фінанси, право. 2013. № 4. С. 143-149.

5. Лопушняк Г.С. Рибчинська Х.В. Державні гарантії забезпечення соціальноекономічних прав в Україні: конституційні засади та рівень практичної реалізації. Соціально-трудові відносини: теорія та практика. 2015. № 1. С. 61-72.

6. Бойко I. В., Бойко О. І. Поняття та види трудових відпусток в Україні. Науковий вісник публічного та приватного права, 2019. № 2. С. 126-133.

7. Кодекс законів про працю: Закон України від 10.12.1971 № 322-VIII. Відомості Верховної Ради УРСР. 1971. № 50.

8. Про професійні спілки, їх права та гарантії діяльності: Закон України від 15.09.1999 № 1045-ХIV. Відомості Верховної Ради України (ВВР). 1999. №. 45. С. 397.

\section{References}

1. Popova, V. M. (2013). Sotsialni prava liudyny - osnova sotsialnoi derzhavy. Efektyvnist derzhavnoho upravlinnia, 37, 70-75 [in Ukrainian].

2. Yaroshenko, A. S. (2018). Osoblyvosti pravovoho rehuliuvannia vidpustok, yak harantii derzhavy, shcho nadaietsia pratsivnyku. Aktualni problemy trudovoho 
zakonodavstva, zakonodavstva pro derzhavnu sluzhbu ta sluzhbu $v$ pravookhoronnykh orhanakh, 1, 239-242 [in Ukrainian].

3. Khromei, V. V. (2013). Realizatsiia konstytutsiinoho prava na vidpochynok. Zovnishnia torhivlia: ekonomika, finansy, pravo, 4, 143-149 [in Ukrainian].

4. Lopushniak, H.S. Rybchynska Kh.V. (2015). Derzhavni harantii zabezpechennia sotsialno-ekonomichnykh prav $\mathrm{v}$ Ukraini: konstytutsiini zasady ta riven praktychnoi realizatsii. Sotsialno-trudovi vidnosyny: teoriia ta praktyka, 1, 61-72 [in Ukrainian].

5. Boiko, I. V., Boiko, O. I. (2019). Poniattia ta vydy trudovykh vidpustok v Ukraini. Naukovyi visnyk publichnoho ta pryvatnoho prava. 2, 126-133 [in Ukrainian].

N. Pilipchuk, Postgraduate student of the Institute of State and Law named after V. M. Koretsky NAS of Ukraine

ORCID: 0000-0002-5553-8524

\section{Problems of providing constitutional rights of human and citizens on recreation in Ukraine}

In the article the problems of ensuring the constitutional right of man and citizen to rest in Ukraine are analyzed. The contents of each of the following issues have been identified. Justified how legislative gaps affect practice. Clear and wellreasoned suggestions are made to address these issues. It is emphasized that in the conditions of martial law and state of emergency the exercise of the right to rest may be restricted, but it is at the level of the Constitution of Ukraine that the limits of such restriction should be specified or the obligation of legislative regulation of the issue determined. In addressing the issue of maximum load, it is important to take into account not only the achievement of the result, but also the harm to health and its equal distribution among all employees. It is worth emphasizing the obligation of the employer and the state authorities to ensure and control the observance of equal workload and responsibility, both disciplinary and material for its non-compliance. The relationship between the right to rest and other constitutional rights has been identified. However, it is important to differentiate them, since caring for a child, even though he or she needs to be released from work, cannot be considered a holiday. With regard to the provision of vacations, breaks and weekends, it may, in the first place, be implemented through the establishment of working time restrictions and the determination of duration of rest. Within the framework of constitutional regulation, it is only necessary to establish the direction and principles, not only the list of forms of implementation. Another problem is the lack of detail in the legal regulation of night time restrictions on daylight saving time, as the actual working time changes. It also requires adjusting holidays and weekends. It has been established that the constitutional right to an employee's leave and the corresponding employer's duty are defined at the legislative level, but the guarantees of its implementation are insufficient. This situation is associated with the existence of significant loopholes and conflicts of law, which give rise to the following problems in ensuring the constitutional right of the person and the 
citizen to rest: the existence of discrimination on religion; lack of principles for restriction of the right to rest; gaps in the powers of trade unions.

Keywords: problems of providing of law; constitutional law; man and citizen; right to rest; constitution. 